\title{
Hypopharyngeal Cancer pT1 TNM Finding v8
}

National Cancer Institute

\section{Source}

National Cancer Institute. Hypopharyngeal Cancer pT 1 TNM Finding v8. NCI Thesaurus.

Code C132929.

Hypopharyngeal cancer with tumor limited to one subsite of hypopharynx and/or $2 \mathrm{~cm}$ or smaller in greatest dimension. (from AJCC 8th Ed.) 